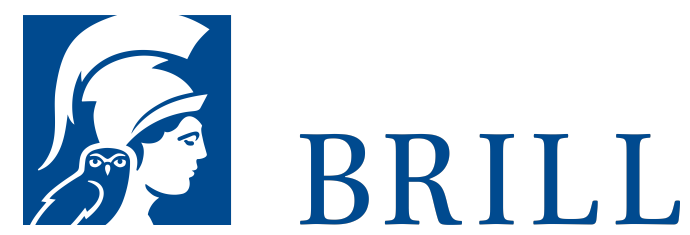

\title{
Ancient Worlds in Digital Culture
}

\section{Editors: Claire Clivaz, Paul Dilley, and David Hamidović}

The volume presents a selection of research projects in Digital Humanities applied to the "Biblical Studies" in the widest sense and context, including Early Jewish and Christian studies, hence the title "Ancient Worlds". Taken as a whole, the volume explores the emergent Digital Culture at the beginning of the 21st century. It also offers many examples which attest to a change of paradigm in the textual scholarship of "Ancient Worlds": categories are reshaped; textuality is (re-) investigated according to its relationships with orality and visualization; methods, approaches and practices are no longer a fixed conglomeration but are mobilized according to their contexts and newly available digital tools.

Readership

All interested in the crossroads between Digital Humanities and Biblical, Classical, Early Jewish and Christian Studies.

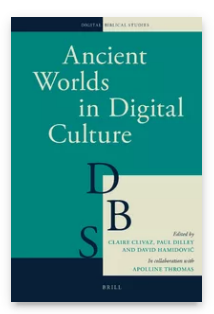

Pages: $\mathrm{x}, 258 \mathrm{pp}$.

Language:

English

Subjects:

General, Biblical

Studies, General, Jewish Studies, Jewish History \& Culture, History, Writing \&

Communication,

Languages and

Linguistics,

Cultural Studies, Social Sciences

Publisher: Brill

Series:

Digital Biblical

Studies, Volume:

1

E-Book (PDF)

Released online:

15 Aug 2016

ISBN: 978-90-

04-32523-4

List price

USD $\$ 124.00$

Hardback

Publication date:

23 Sep 2016

ISBN: 978-90-

04-32247-9

List price 
Claire Clivaz, Ph.D. (2007), University of Lausanne (CH), is Head of Digital Enhanced Learning at the Swiss Institute of Bioinformatics, VITAL-IT. She has published on New Testament, Christian apocryphal literature and Digital Humanities.

Paul Dilley, Ph.D (2008), Yale University, is an Assistant Professor of Ancient Mediterranean Religions at the University of Iowa, and a member of the Public Digital Humanities initiative. He has published widely on early Christian asceticism/monasticism, Manichaeism, and apocryphal literature.

David Hamidović, Ph. D. in History of Antiquity (2003), Sorbonne University, is Full Professor at the chair "Jewish apocryphal literature and history of Judaism in Antiquity", at the University of Lausanne, Switzerland. He has published monographs and articles on Ancient Judaism and Digital Humanities.

For more information see brill.com

Order information: Order online at brill.com +44330 3330049 | customerservices@brill.com Submission information: brill.com/authors

Titles published by Brill | Fink, Brill | mentis or Brill | Schöningh: +49(o)71 5413279216 | brill@brocom.de 